Short note

\title{
Baiting system for selective abatement of undesirable honey bees
}

\author{
J.L. Williams, R.G. Danka and T.E. Rinderer \\ USDA, ARS Honey-Bee Breeding, Genetics and Physiology Laboratory, 1157 Ben Hur Road, Baton \\ Rouge, LA 70820 United States
}

(received 6 June 1988, accepted 20 January 1989)

\begin{abstract}
Summary - Acephate at $250 \mathrm{ppm}(\mathrm{mg} / 1)$ in a sucrose-honey syrup bait placed $10 \mathrm{~m}$ from the hive was tested for efficacy in destroying honey bee colonies. Untreated training syrup was replaced with acephate-treated syrup during active foraging; bees continued collecting treated syrup for $c 30$ min before becoming intoxicated. Queens in 13 of 19 colonies died without natural replacement within $3 \mathrm{~d}$ after treatment, two queens died but were successfully replaced, and four queens remained alive. Colonies that were rendered permanently queenless had collected an average of $74 \mathrm{ml}$ of syrup and lost most of their adult workers and all larvae within 1 wk. Preliminary results show the baiting system to have potential use in an Africanized bee abatement program because it is effective, relatively safe, and, due to a limited, managed exposure time, selective for honey bees.
\end{abstract}

Africanized honey bee - eradication — insecticide bait - acephate

Résumé - Système d'appât pour la destruction sélective des abellles Indésirables. On a étudié l'efficacité de l'insecticide organophosporé acéphate pour éradiquer les colonies d'abeilles (Apis mellifica L.), lorsqu'il est récolté par les butineuses. Celles-ci ont été dressées à récolter à $10 \mathrm{~m}$ de la ruche un sirop de saccharose à $50 \%$, contenant $10 \%$ de miel comme appát. Les abeilles prélevaient le sirop ad libitum à 50 trous de $1 \mathrm{~mm}$ situés sur le pourtour d'un nourrisseur en position inversée. Le sirop non traité a été remplacé par du sirop contenant $250 \mathrm{ppm}(\mathrm{mg} / \mathrm{l})$ d'acéphate (Orthene 75 S) durant la période active de butinage. Les abeilles ont récolté le sirop traité pendant 30 min environ avant d'être intoxiquées.

Les colonies qui ont récolté $74 \mathrm{ml}$ de sirop en moyenne ont perdu la plupart de leurs ouvrières adultes et toutes lours larves en l'espace d'une semaine. Les reines de 13 des 19 colonies sont mortes dans les 3 jours suivant le traitement, sans être remplacées naturellement, deux reines sont mortes mais ont pu être remplacées et quatre sont restées vivantes (Tabl. I). Le système d'appât présente des potentialités pour être utilisé dans un programme de lutte contre l'abeille africanisée, parce qu'il est efficace, relativement sûr et sélectif pour les abeilles en raison du temps réduit d'exposition.

abellle africanisée - éradication - système d'appât - acéphate

Zusammenfassung - Köderfallen für die selektlve Bekämptung von unerwünschten Honigbienen. Die Wirksamkeit von Acephat (Orthene ${ }^{(75 S)}$ nach Aufnahme durch Sammel- 
bienen als Mittel zur Ausrottung von Völkern der Honigbiene wurde untersucht. Sammelbienen wurden auf eine Köderfalle mit 50\%igem Saccharosesirup und 10\% Honig in $10 \mathrm{~m}$ Entfernung vom Stock trainiert. Die Bienen konnten den Sirup ad libitum von 50 Löchem (o $1 \mathrm{~mm}$ ) am Rand einer umgestülpten Futterdose abnehmen. Der reine Sirup wurde während der aktiven Flugperiode durch Sirup mit 250 ppm (mg/l) Acephat (Orthene 75S) ersetzt; die Bienen setzten die Sammelflüge noch $30 \mathrm{~min}$ fort, bevor sie die ersten Anzeichen von Intoxikation zeigten.

Völker, die etwa $74 \mathrm{ml}$ Sirup aufgenommen hatten, verloren innerhalb von einer Woche die meisten ihrer Sammelbienen und alle Larven. In 13 von 19 Völkern starben die Königinnen ohne natürliche Umweiselung innerhalb von drei Tagen nach der Behandlung; zwei Königinnen starben, wurden aber erfolgreich ersetzt, und vier Königinnen überlebten. Das Köderfallensystem scheint also für ein Bekämpfungsprogramm gegen afrikanisierte Honigbienen geeignet, weil es wirksam ist, relativ sicher und infolge der geringen Darbietungszeit selektiv für Honigbienen.

afrlkanislerte Honigbienen - Ausrottung - Köderfallen - Acephat

\section{Introduction}

The continuing expansion of the range of Africanized honey bees in the Americas has prompted discussions of methods to suppress undesirable bee populations (Gary, 1971, 1985; Rinderer et al., 1987; Stibick, 1984; USDA, 1987). A potentially useful technique for eradicating undesirable honey bees would be a baiting system in which toxicants were delivered to remote colonies by foragers (Gary, 1971; USDA, 1987). Such a system must meet several requirements. Above all, the toxic bait must not be repellent, must have delayed toxicity to allow delivery to the nest, and should render a colony permanently queenless, or irreversibly disrupt brood rearing. Achieving permanent queenlessness is particularly difficult because the queen often survives when colonies are poisoned, and, together with eclosing workers, may enable colony survival (Atkins, 1975).

Previous reports suggest that the systemic organophosphate acephate might achieve the requirements of a baiting system. Long-term feeding of 10 ppm acephate to honey bees caused severe toxicity to workers, and often led to the death of the queen and the subsequent inability of the colony to rear a replacement queen (Stoner et al., 1985). In addition, small colonies fed $1.0 \mathrm{ppm}$ acephate for $14 \mathrm{~d}$ showed poor worker survival $(<25 \%)$ and queen survival, and ceased brood rearing (Fiedler, 1987).

Preliminary tests from August 1987, through March 1988, using acephate at $10-25 \mathrm{ppm}$, gave variable results. When worker mortality was moderate or high, however, the queen also typically died. The main difficulty seemed to be in consistently delivering sufficient quantities of acephate to target colonies. Repellency did not appear to be a problem, so we sought to overcome the problem of insufficient toxicant by increasing the concentration to $250 \mathrm{ppm}$.

\section{Materials and Methods}

Testing took place in April, 1988, during a time of poor nectar availability. Four replications of five colonies each were conducted; data from one colony (no. 244) initially treated to screen for repellency are also included. Single colonies were moved to sites at Baton Rouge and St. 
Gabriel, LA, which were relatively isolated from known apiaries. Colonies consisted of an average of $c 20,000$ adult bees $(7$ combs covered with bees; range $5.5-8.5$ combs), a laying queen, a normal broodnest on 4-6 combs, and stored honey and pollen. They were housed in single-story $(16.6 \mathrm{~cm}$ hive bodies), 10-frame Langstroth hives. Hive entrances were fitted with queen excluders to aid in recovering dead queens and also to help retain adult workers that were killed. A 56- $x$ 47$\mathrm{cm}$ tray in front of the hive also collected dead bees.

Colonies were trained to forage at bait stations (Danka et al., unpublished observations) placed $c 10 \mathrm{~m}$ from each hive. The bait consisted of $50 \%(\mathrm{~V} / \mathrm{V})$ sucrose solution plus $10 \%(\mathrm{~V} / \mathrm{v})$ honey. Foraging bees took the sugarhoney syrup ad libitum from $c 501$-mm holes around the rim of an inverted 946-ml feeder can. Immediately before treatment, observations of flight paths at each site verified that foragers came only from the target colonies.

After 1-3 d of training, the colonies were treated with acephate (Orthene ${ }^{\circledR} 75$ S1) by replacing the feeder used for training with a feeder containing $500 \mathrm{ml}$ of the sucrose-honey syrup plus $250 \mathrm{ppm}(\mathrm{mg} / \mathrm{l})$ acephate. Bees on the feeder were counted at 5-min intervals until foraging had ceased, usually $c 30 \mathrm{~min}$ later. The counting method measured the maximum number of bees foraging simultaneously. The weight of syrup consumed was measured during some treatment sessions; the volume of syrup removed was calculated from the weight change.

Colonies were moved into a holding apiary 1 d after treatment. Adult mortality, brood mortality, and queen cell construction were monitored until it could be determined that a colony was permanently queenless, had successfully replaced a killed queen, and was recovering, or continued to appear normal.

\section{Results}

Queens in 13 of 19 colonies died within 3 d after treatment and were not replaced
(Table 1). These permanently queenless colonies had an average maximum of 147 foragers simultaneously on a feeder during treatment; on average, $74 \mathrm{ml}$ of acephate-treated syrup was collected ( $n=$ 10). The fatally poisoned colonies averaged $c 2000$ dead bees during the $24 \mathrm{~h}$ post-treatment period; dead bee counts 5 days after treatment were generally $c 2-3$ times greater. Conversely, the 6 colonies in which the queen was successfully replaced or was normal had an average maximum of 65 bees foraging, collected $43 \mathrm{ml}$ of treated syrup, and had $c 800$ dead bees during the $24 \mathrm{~h}$ post-treatment period. Throughout the test, the bottom board and tray retained only an estimated $25-35 \%$ of dead bees as most bees died away from the hive.

Collection of an average of $74 \mathrm{ml}$ of 250 ppm acephate-treated syrup usually resulted in effective destruction of the colonies (death of the queen, most adult bees, and all unsealed brood) within $3 \mathrm{~d}$. When poisoned, remaining bees usually ceased normal activities : foraging stopped, the brood was abandoned, and bees clustered on the top bars and sides of the hive. Poisoned bees tended to walk rather than fly, and were not defensive. Larvae may have died as a result of a lack of care or from intoxication.

Repellency of syrup bait containing 250 ppm acephate was not observed. Foraging was greatest $c 10 \mathrm{~min}$ after replacement of the untreated syrup with treated syrup, then declined to 0 during the next $20-30 \mathrm{~min}$ as bees became intoxicated.

This article reports the results of research only. Mention of a pesticide does not constitute recommendation by the U.S. Department of Agriculture for use, nor does it imply registration under FIFRA as amended. 
Table I. Responses of honey bee colonies collecting sucrose syrup - honey baits containing 250 ppm (mg/) acephate. Tests were conducted at Baton Rouge and St. Gabriel, Louisiana. Summaries in lower section are $\bar{x} \pm s d(n)$.

\begin{tabular}{|c|c|c|c|c|c|c|}
\hline Rep. & Date & $\begin{array}{l}\text { Col. } \\
\text { no. }\end{array}$ & $\begin{array}{c}\text { Max. foragers } \\
\text { on feeder }\end{array}$ & $\begin{array}{c}\text { Volume } \\
\text { syrup } \\
\text { removed }(m l)\end{array}$ & $\begin{array}{l}\text { Queen } \\
\text { fate }\end{array}$ & $\begin{array}{c}24-h \\
\text { worker } \\
\text { mortality }\end{array}$ \\
\hline I & 4-IV-88 & 244 & 200 & - & Died 6-IV & - \\
\hline$\|$ & $7-I V-88$ & $\begin{array}{c}12 \text { (control) } \\
46 \\
45 \\
50 \\
37\end{array}$ & $\begin{array}{c}200 \\
90 \\
175 \\
63 \\
70\end{array}$ & $\begin{array}{c}1000 \\
147 \\
- \\
97 \\
97\end{array}$ & $\begin{array}{l}\text { Normal } \\
\text { Died } \\
\text { Replaced } \\
\text { Normal } \\
\text { Died }\end{array}$ & $\begin{array}{r}1 \\
1701 \\
2074 \\
1359 \\
2254\end{array}$ \\
\hline III & 14-IV-88 & $\begin{array}{c}15 \\
151 \\
27 \\
35 \\
167\end{array}$ & $\begin{array}{c}150 \\
41 \\
200 \\
200 \\
92\end{array}$ & $\begin{array}{l}- \\
\overline{42} \\
61 \\
74\end{array}$ & $\begin{array}{l}\text { Died 16-IV } \\
\text { Died 17-IV } \\
\text { Died 16-IV } \\
\text { Died 17-IV } \\
\text { Died 16-IV }\end{array}$ & $\begin{array}{l}1026 \\
1021 \\
1209 \\
1389 \\
1466\end{array}$ \\
\hline IV & $20-$ IV-88 & $\begin{array}{c}140 \\
41 \\
128 \\
31 \\
135\end{array}$ & $\begin{array}{c}147 \\
18 \\
200 \\
28 \\
200\end{array}$ & $\begin{array}{l}67 \\
22 \\
78 \\
24 \\
68\end{array}$ & $\begin{array}{l}\text { Died 23-IV } \\
\text { Normal } \\
\text { Died 22-IV } \\
\text { Normal } \\
\text { Died 21-IV }\end{array}$ & $\begin{array}{c}2928 \\
499 \\
4314 \\
312 \\
2740\end{array}$ \\
\hline V & $22-I V-88$ & $\begin{array}{c}48 \\
161 \\
175 \\
196 \\
4 \text { (control) }\end{array}$ & $\begin{array}{c}79 \\
76 \\
27 \\
250 \\
58\end{array}$ & $\begin{array}{c}30 \\
28 \\
- \\
79 \\
99\end{array}$ & $\begin{array}{l}\text { Replaced } \\
\text { Died 24-IV } \\
\text { Normal } \\
\text { Died 25-IV } \\
\text { Normal }\end{array}$ & $\begin{array}{r}136 \\
207 \\
175 \\
1666 \\
67\end{array}$ \\
\hline \multicolumn{7}{|c|}{ Queen fate category } \\
\hline Died : & & & $\begin{array}{c}147 \pm 67 \\
(13)\end{array}$ & $\begin{array}{c}74 \pm 32 \\
(10)\end{array}$ & & $\begin{array}{c}1827 \pm 1090 \\
(12)\end{array}$ \\
\hline \multicolumn{3}{|c|}{ Replaced or normal : } & $\begin{array}{c}65 \pm 59 \\
(6)\end{array}$ & $\begin{array}{c}43 \pm 36 \\
(4)\end{array}$ & & $\begin{array}{c}759 \pm 786 \\
(6)\end{array}$ \\
\hline \multicolumn{3}{|c|}{ Control: } & $\begin{array}{c}129 \pm 100 \\
(2)\end{array}$ & $\begin{array}{c}550 \pm 637 \\
\text { (2) }\end{array}$ & & $\begin{array}{c}34 \pm 47 \\
\text { (2) }\end{array}$ \\
\hline
\end{tabular}

\section{Discussion}

Acephate collected in relatively small amounts by foragers devastated most colonies. Ten of 11 treated colonies suffered extensive adult and brood mortality and became permanently queenless within $1 \mathrm{wk}$ after a maximum of $80-200$ bees were observed collecting syrup simultaneously. Three of 5 colonies having only $41-79$ bees foraging on the baits were also effectively destroyed. Thus the preliminary results from using 
the baiting system are very encouraging. Simultaneous visitation by 100 or more bees is quite common on sucrose syrup baits within $2-3 \mathrm{~d}$ after discovery by bees during a dearth (unpublished observation). The reasons for the few discrepancies in the relationship between volume of acephate-treated syrup collected and colony mortality were not apparent.

The major disadvantage of baiting is the risk associated with all pesticide use, the potential effects on non-target organisms. Fortunately, impact on nonApis species at the bait stations can be minimized because the treatment procedure is rapid and selective. Since only $c 30 \mathrm{~min}$ of treatment is required, selectivity is achieved by presenting treated syrup when only honey bees are visiting the bait stations. Species other than honey bees never interfered with these tests. Acephate also has low mammalian toxicity (male rat acute oral $\mathrm{LD}_{50}=945 \mathrm{mg} / \mathrm{kg}$; Entomol. Soc. Am., 1981). When honey bees are poisoned, contaminated materials may remain in the nest. Stoner et al. (1985), however, found complete degradation of $10 \mathrm{ppm}$ acephate in syrup after $1 \mathrm{wk}$. The relative safety of acephate, in combination with the selectivity of the baiting system, gives a treatment procedure that is likely to satisfy environmental impact concerns.

\section{Acknowledgments}

We thank C. Dean Brister, James Baxter, Jose Villa and J. Anthony Stelzer for assistance in the field, and Charles Richardson, Station Superintendent, for providing access to the St.
Gabriel Research Station. From the Louisiana State University. Thomas Sparks gave helpful discussion and Jerry Graves, Dale Pollet, Sharron Quisenberry and Gene Reagan donated insecticides during preliminary testing. This research was completed in cooperation with the Louisiana Agricultural Experiment Station.

\section{References}

Atkins E.L. (1975) Injury to honey bees by poisoning. In : The Hive and the Honey Bee. Dadant and Sons, Hamilton, Illinois, pp. 663696

Entomological Society of America (1981) Pesticide Handbook. ENTOMA, 29th ed. Entomol. Soc. Am. College Park, Maryland

Fiedler $L$. (1987) Acephate residues after preblossom treatments : effects on small colonies of honey bees. Bull. Environ. Contam. Toxicol. 38, 594-601

Gary N.E. (1971) Possible approaches to controlling the African bee. Am. Bee J. 111, 426-429

Gary N.E. (1985) The Africanized honey bee : ahead of schedule. Calif. Agric. 39, 4-7

Rinderer T.E., Wright J.E., Shimanuki H., Parker F., Erickson E. \& Wilson W.T. (1987) The proposed honey-bee regulated zone in Mexico. Am. Beө J. 127, 160-164

Stibick J.N.L. (1984) Animal and Plant Health Inspection Service Strategy and the African honey bee. Bull. Entomol. Soc. Am. 30, 22-26

Stoner A., Wilson W.T. \& Harvey J. (1985) Acephate (Orthene ${ }^{8}$ ) : effects on honey bee queen, brood and worker survival. Am. Bee J. $125,448-450$

U.S. Department of Agriculture (1987) Action

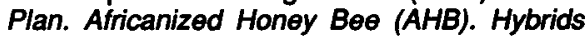
of Apis mellifera scutellata Lepeletier. Animal and Plant Health Inspection Service, Program Planning Staff. Government Printing Office, Washington, D.C. 